\title{
Electronic Library: Genesis, Trends. From Electronic Library to Smart Library
}

\author{
Ruslan A. Baryshev*, \\ Olga I. Babina, Pavel A. Zakharov, \\ Vera P. Kazantseva and Nikita O. Pikov \\ Siberian Federal University \\ 79 Svobodny, Krasnoyarsk, 660041, Russia
}

Received 29.01.2015, received in revised form 16.03.2015, accepted 21.04.2015

The article proposes to discuss the main trends in the development of electronic libraries and prerequisites for the transition to a new level, to smart libraries. The text presents a historical overview of the formation of the electronic library concept both in Russia and abroad. Disambiguation of electronic library term is separately covered, as well as synonymous terms it has in Russia. At the same time, they often stay within a common understanding of a digital library within the framework of western theorizing.

A wide range of electronic library problems is discussed in the context of multitasking understanding of the librarianship role in the public and university areas. Approach differences are pointed out in account of university tasks specifity.

As a solution, the authors propose a new approach for constructing smart library by identifying and fixing the purposes of the user. Approach reverses the paradigm of library consciousness, indicating that the primary role in the library is given to the reader that is at odds with most of the current thinking about the library as a space, funds and staff. The text discloses an approach in which relying on modern technology makes possible to significantly reduce its importance and bring into researcher's focus the needs and the role of the reader.

Keywords: electronic library, smart library, library, library services.

Research area: pedagogy, economics.

\section{Introduction}

Electronic library (EL) development, which became possible with the advent of highperformance software and hardware systems, communication channels and specialized application software, caused explanatory activity in this area. Theoretical studies and generalization of practical implementation of EL development projects contributed to the formation and development of conceptual construct, including the introduction of new terms and definitions. Herein, the EL definition changes and updates in accordance with the evolution of the understanding of EL goals, its objects and purpose. For more accurate and comprehensive definition of EL researchers employ a variety of approaches such as classification and generalization of the known definitions [10], generalization of the various

(C) Siberian Federal University. All rights reserved

* Corresponding author E-mail address: r_baryshev@bk.ru 
definitions, highlighting some of the key features of EL (technology, purpose, funds and others) [16], and also classification of the most well-known EL definitions within functional, technological and resource-technological approaches [6].

EL definitions at various times were suggested by researchers Alexander Antopolsky, Constantin Vigursky [33], Evgeni Gorny [35], Yakov Shraiberg, Felix Voroisky, Tatiana Maistrovich and many others.

Definition "electronic library" is often used as a synonym for virtual library and digital library. However, experts place in question equvalence of these definitions. Thus Yury Stolyarov, well-known theorist of librarianship, defining the term "virtual library", wrote that "this expression is metaphorical, non-strict, conditional”, continuing: “...it has synonyms: automated, electronic, computer, online.” [28]. Eduard Sukiasyan, expert in the field of library terminology, noting the differences in terms of "digital library" and "electronic library", stated: "...the term "electronic library" is the most practical for defining such libraries" [30].

Updating of EL definition reflects prevalent in different periods of libraries development understanding of the role and the purpose of EL, ways to interact with the traditional library. To a great extend definition differences are due to specific expertise of information technology integration into library activity, adaptation of current library activity to changing reader needs, and education technology development. It may be noted that the most intense changes in the EL area, reflected in the EL definition as well, almost always coincided with significant changes in information and communication technologies, such as transition to ideas and principles of the Internet 2.0. The concept of Internet 2.0, announced by Tim O'Reilly in 2005, inspired researchers to formulate definitions and principles of Library 2.0, which allows considering features of the Internet new virtual environment [24, 25]. The basis for the formation of modern approaches to library development is the concept of "information society" and associated changes in social and economic systems.

The term "information society" was implemented in scientific use in the early " $60 \mathrm{~s}$ almost simultaneously in the US and Japan by Fritz Machlup [18] and Tadao Umesao, the authors, who have become widely known for their studies of the knowledge-intensive industries dynamics. Japanese researchers had a great influence on the development of the "information society" concept. The term "information society", introduced by Tadao Umesao, received worldwide recognition after the publication of a book by Yoneji Masuda [19]. Russian scientists Nikita Moiseev, Anatoly Rakitov, Georgy Smolyan, Dmitry Chereshkin made contribution to comprehension of the information society features. Significant contribution to the understanding of the postindustrial society in the context of Russian conditions was made by Vladislav Inozemtsev [12]. Starting from the second half of the $80 \mathrm{~s}$, American researchers began to focus on the role and importance of knowledge rather than information, which gave rise to a whole range of new definitions of modern society, including such definitions as "knowledge society", "knowledgeable society".

"Information society" formation is based on the advances in information technology. The development of this area has a significant impact on the EL activity and requires consideration during planning of changes in libraries. Analysis of the IT development allows identifying the main trends in the field of modern information and telecommunication technologies. According to IDC, the main growth drivers in 2015 will be cloud and mobile technologies, social networks and Big Data [11]. All indicated trends determine the prospects of EL. The penetration of the 
"information society" in professional sphere and everyday life creates new standards of information resources search and providing. New standards of Internet portals user interface stimulate the transfer of the most successful and popular solutions from the space of Internet to the library space.

\section{Current state of the problem}

Currently, EL often exists in the form of additional structure of functioning traditional library. For which reason the EL is associated with the presence of an electronic catalog in a library. However, some time ago, in the framework of understanding EL occurred detachment from the physical infrastructure, required to serve readers, and emphasis has shifted toward the virtual part in the defined concept. Electronic resources, medium access and features of virtual reader service became the main defining aspects of EL entity [17]. Intensive and systematic development of distance education, using its own information resources, reduces the motivation of students to search for additional study materials. Changes of library "environment", occurred over the past ten years, are obvious and significant. The development of the Internet as a means of obtaining necessary information resources by a modern person greatly complicates the activity of traditional libraries and electronic libraries, based on those. The constant availability of online knowledge dictates requirements for the organization of readers-library interaction with account of the latest technological innovations. Currently an obvious need for personalizing the library service has been formed.

There is a crisis of not only traditional libraries, but EL, created on their basis. EL, as well as a traditional library, implements the main function - the function of providing the reader with necessary information. This function realization requires addition and correction of approaches to EL activity. At the same time, the most important EL component, indicating the need for data structuring, has not lost but increased the urgency due to the recent appearance of many non-text data types. Integration of useful changes in the library activity is not always successful. For example, practical embodiment of Library 2.0, integrating achievements of Web 2.0, has proved to be extremely difficult. This is due to the fact that technological innovations, implemented in the Web 2.0, could not be fully integrated into the library, being a contrary to some of the basic library criteria and, above all, the need to organize the data on the basis of strict rules and regulations, which are necessary to describe resources.

Underrun of the changes in the library from changes in the "environment" could lead to the isolation of libraries in social space. A new step in the adaptation of libraries to external changes and demands of readers is required. We can state that the background to create libraries of new qualitative level has formed. We denote it as a smart library.

\section{Research methodology}

Research in this sphere is based on fundamental works of Yury Stolyarov, Anatoly Vaneev, Nikolay Kartashov [29, 34, 13], which put forward and analyzed the concept of a library as a system and its functions as a whole; in the methodology area of open and electronic learning are used known works of Andrey Andreev, Vladimir Tikhomirov [1, 31]. Among the works on the problems of positioning libraries in the educational environment as well as the organization of university library work could be mentioned publications by Tatiana Eremenko, Galina Kudryashova, Svetlana Galaktionova [5, $15,7]$. Application-specific questions of library activity are covered in research papers in the field of electronic library organization, automated 
library systems and Internet-based systems by authors: Yakov Shraiberg, Felix Voroisky, Andrey Zemskov, Alexander Antopolsky, Tatiana Maistrovich, Constantin Kolossov [37, 36, 2, 9, 8].

Papers in the field of smart education reflect the new paradigm of western education, socalled "The Learning Explosion". The following technologies are used in the organization of modern education: virtual classroom, social media, online communities, Wiki-resources, mobile applications, podcasts, blogs, research websites [23]. Fragments of knowledge, pieces of information, obtained from a variety of sources, are integrated into the new base system. Virtual classroom creates educational environment in the virtual space in order to improve access to advanced educational practices through remote interaction between students and teachers. Wikiresources form an adaptive help system. Research sites provide a practical usage of knowledge skills.

Contribution to studies of the information society was made by Russian researchers Nikolay Moiseev, Anatoly Rakitov, Georgy Smolyan, Ivan Melyuhin [21, 26, 27, 20].

\section{Discussion}

Noteworthy attempts were made in last 5-7 years to study features of EL with an emphasis on reader service and maintenance procedures, as well as the definition of the EL essence through the introduction of terms defining the library with relation to the organization of these services. J. Needham and M.Alley analyze library services and outline following services, which can be provided by library to users in the information space: request/inquiry, book circulation, representation and visibility, alerting, syndication, mobile websites, communication, reservations, notes and records [22]. In this field of research are "Network" and "Mobile" library, and a relatively new term - "Smart Library". Smart library is more general concept, based on a statement of the fact that the main place in a library devoted to service and consumer, not infrastructure, personnel, funds and so on as it was some time ago. This concept is characterized by a tendency to structure a library by function types with division of those functions that can be implemented using existing software and hardware systems and those that are to be partially or fully supported by library staff.

Smart library, as a concept, reflects the response to such processes as universal informatization and internetization. On the one hand, these processes lead to "information tsunami", which cannot be repelled by a person, and on the other hand, give rise to a user's need for point "rubbish-free" information, which can only be provided by analytically trained librarians and / or "smart" information systems. It may be noted that at present the "correct" smart library services are becoming in-demand.

The definition of smart library could be pre-formulated in terms of library services in a following way: "smart library" is a set of various electronic resources, accompanied by specialized library services, which are provided by the use of information and communication technologies.

Smart library is a new quality of a library in which the expert usage of hardware, services and Internet leads to qualitative changes in the user-librarian interaction, allowing acquisition of new effects for better service. Smart library organizes the "smart" work based on the "smart" infrastructure, taking into account the needs of users, who play an important role in the development of library smart culture. Technology in the smart library, previously based on information and knowledge, is transformed into technologies, based on interaction and exchange of experience - smart technology. Smart library, using technological innovation and 
the Internet, provides users with the opportunity to acquire knowledge on the basis of the system multidimensional vision of knowledge.

Following ideas form the basis of smart library concept:

- Creating of smart environment - certain services and technological developments have reached a high level, allowing the development of environment, which begins to approach the natural intelligence;

- Mobile access - availability of all digital service types anywhere in the world. These services should be aimed at each user individually;

- New knowledge creation - on the basis of collective creativity, with the involvement of expert groups, using social networks;

- Active content - simply placing the content in the repository is not enough for it to become active. All objects must be interconnected. In turn, the quality of the repository must be monitored due to the introduction of such systems as e-metrics, and work as a team [31].

- Adaptivity-the formation of a customized service set for user requests. Large number of sources, the maximum diversity of media (audio, video, graphics), the ability to quickly and easily adjust to the level and needs of a user.

Smart library creation is only possible on the basis of new information and communication technologies and library technology. Such technologies contain the following:

- Smart technology of content formation, semantic structuring of the content of scientific digital libraries on the basis of ontology [14]. Organization of scientific electronic libraries information resources, providing their semantic structuring. Content of electronic library, enriched with semantic links, allows scientometric measurement based on the classification of relations between its data objects, provides new opportunities for the analysis of scientific knowledge body and new forms of interactive science activities. Content formation is based on expert opinions (e.g., in a university, it is based on recommendations of teachers). Usage of information recommended for reading for the formation on the basis of "collective creativity" in the social network;

- Smart detection of knowledge. Usage of information on citation for generating new knowledge. Formation of new ontological relations, building new ontology.

- Smart interface (organization of interaction with the user). Interface that allows interaction with users, the analysis of user actions to record and replicate "successful" search strategies.

- Smart services (e.g., personal informing). Selective Dissemination of Information (SDI) allows systematic receiving of signaling information on new publications and documents by permanent and one-time requests formulated by users. Differentiated Services for Authority (DOA) contributes to leaders' reasoned decisions on specific issues, problems, questions.

- Mobile applications usage. Providing summary information via mobile devices and applications.

All of these technologies are not new, but well tested in different application areas. However, most of these technologies are not in use in librarianship. Personal account, the widely used technology, makes these solutions more promising. Creating a reader personal account, including even $30 \%$ of the services 
provided by the library, will propel a library to the next level of service. Experts of Scientific Library of Siberian Federal University have started to develop a number of services which, if successfully implemented, will create a smart library in SFU. As a first step, the developers create a reader personal account with reference to it those services, the need for which is already known. Basic service features providing studying literature to students on the basis of his/ her academic disciplines. It is a complicated task, which requires download of a data set, including data on academic subjects for the next few years. On the basis of these plans electronic resources necessary for teaching the reader will be included into the system (personal account) $[3,4]$.

\section{Conclusion}

The transition to smart library will eliminate some of the risks and disadvantages of existing library systems. The implementation of a fully functional smart library is possible through the consistent implementation of individual smart mechanisms and/or smart functions. For instance, providing personalized information resources via personal account. This work is currently going on in Siberian Federal University and the results can be measured as positive.

\section{References}

1. Andreev, A.A. Didakticheskie osnovy distantsionnogo obrazovaniia v vysshikh uchebnykh zavedeniiakh [Didactic Basics of E-learning in Higher Educational Institutions]: Thesis of Doctor of Pedagogy. Moscow, 1999. 289 p.

2. Antopol'skiy, A.B. Maistrovich, T.V. Elektronnye biblioteki: printsipy sozdaniia [Electronic Libraries: Principles of Creation]: Research and Methodological Guide . Moscow: Libereia-Bibinform, 2007. 283 p.

3. Babina, O.I., Baryshev, R.A. Marketing research of the academic library of the siberian federal university. Universal Journal of Management. 2014. T. 2. № 3. C. 138-143.

4. Baryshev, R.A., Tsibul'skiy, G.M., Babina, O.I., Pikov, N.O. K probleme tselevogo obsluzhivaniia pol'zovatelia elektronnoi biblioteki vuza [On the Issue of Target Services for the University Electronic Library User]. Filosofiia obrazovaniia [Philosophy of Education]. No. 4 (55). P. 105-112.

5. Eremenko, T.V. Informatizatsiia vuzovskikh bibliotek v Rossii I SSHA: sravnitel'nyi analiz: monografia [Computerization of University Libraries in Russia and the USA: Comparative Analysis: a Monograph]. Moscow: Pashkkov Dom, 2003. 297 p.

6. Fedorov, A.V. Osnovnye podkhody k opredeleniiu poniatiia "elektronnye biblioteki" [Main Approaches to Determination of the "Electronic Libraries" Definition] [Online Resource]. Available at: http://ideafor.info/?p=1931.

7. Galaktionova, S.P. Dokumentnye resursy vuzovskikh bibliotek kak komponent obrazovatel'noinformatsionnogo prostranstva territorii [Document Resources of University Libraries as a Component of Educational and Informational Space Area]: Thesis of Ph.D. in Pedagogy. Kemerovo, 2004. 220 p.

8. Goncharov, M.V., Kolosov K.A. Prakticheskaia realizatsiia bibliotechnogo internetkompleksa: nauchno-prakticheskoe posobie [Practical Realization of Library Internet Complex: Research and Practical Guide]. Moscow: FAIR-PRESS, 2005. 192 p.

9. Goncharov, M.V. Internet-tekhnologiia v sovremennoi biblioteke [Internet Technologies in Modern Library] // Biblioteki i assotsiatsii v meniaiushchemsia mire: novye formy tekhnologii i novye 
formy sotrudnichestva: materialy konferentsii [Libraries and Associations in the Changing World: New Forms of Technology and New Forms of Cooperation: Conference Materials]. Moscow, 2000. V. 1. P. 208-210.

10. Gorny, E. Razvitie elektronnykh bibliotek: mirovoi i rossiiskii opyt, problemy, perspektivy [Development of Electronic Libraries: International and Russian Experience, Problems and Prospects]/ E. Gorny, K.V. Vigurskiy // Internet i rossiiskoe obshchestvo [Internet and Russian Society] / edited by I. Semenova; Moscow Center of Carnegie. Moscow: Gendal'f, 2002. 279 p.

11. IDC. Predictions 2015: Accelerating Innovation - and Growth - on the 3rd Platform [Online Resource]. - available at: http://www.idc.com/getdoc.jsp?containerId=252700

12. Inozemtsev, L.V. Za predelami ekonomicheskogo obshchestva: Postindustrial'nye teorii $i$ postekonomicheskie tendentsii v sovremennom mire [Outside the Economic Society: Postindustrial Theories and Post-economic Trends in the Modern World]. Moscow, 1998.

13. Kartashov, N.S. Kachestvo upravleniia obuslovleno tekhonologiei [Management Quality Is Provided by Technology]. Biblioteka [Library]. 1999. No. 5. P. 44-46.

14. Kogalovskiy, M.P., Parinov, S.I. Semanticheskoe strukturirovanie kontenta nauchnykh bibliotekna osnove ontologii [Semantic Structuring of contents of Scientific Libraries on the Ontological Basis] [Online Resource]: grant of the Russian Foundation of Fundamental Research 09-07-00378 and the Russian Research Foundation for the Humanities 11-02-12026-в. available at: http://www.cemi. rssi.ru/mei/articles/kogalov11-04.pdf.

15. Kudriashova, G. Iu. Evoliutsiia missii vuzovskikh bibliotek [Evolution of the Mission of the University Libraries]: Thesis of the Ph.D. in Pedagogy: 05.25.03. Cheliabinsk, 2003. 208 p.

16. Lappo, P.M., Sokolov, A.V. Vvedenie v elektronnye biblioteki [Introduction to the Electronic Libraries]. 2005. [Online Resource] / available at: http://old.nlb.by/html/news2005/7july/data/PDF.pdf.

17. Lappo, P.M., Sokolov, A.V. Vvedenie v elektronnye biblioteki [Introduction to the Electronic Libraries] [Online Resource]. 2005. Available at: http://natlib.org.by/html/news2005/7july/data/index. html.

18. Machlup, F. The production and Distribution of Knowledge in the United States. Princeton, 1962.

19. Masuda, Y. The Information Society as Post-industrial Society. Washington, 1981.

20. Meliukhin, I.S. Informatsionnoe obshchestvo: istoki, problemy, tendentsii razvitiia [Information Society: Origin, Problems and Development Trends]. Moscow: Publishing house of Moscow State University, 1999. $176 \mathrm{p}$.

21. Moiseev, Kh.Kh. Chelovek i noosfera [A Man and Anthroposphere]. Moscow: Molodaia gvardiia, 1990. P. 198.

22. Mobil'nye biblioteki. Mobil'nye bibliotechnye onlainovye uslugi [Mobile Libraries. Mobile Library Online Services]: collection of publications / edited by G. Needham, M. Ally; Research Editor Ia.L. Shreiberg, Doctor of Technology, Professor; translated from English by E.V. Maliavskaia, V.V. Zverevich, T.O. Zverevich. Saint Petersburg. Professiia, 2012. 368 p.

23. Murdoch, M., Muller, T. The Learning Explosion: 9 Rules to Ignite Your Virtual Classrooms / Matthew Murdoch, Treion Muller. FranklinCovey Publishing, 2011.

24. O'Reilly, T. What is Web 2.0 / [Online Resource] - Available at: http://www.oreilly.com/ pub/a/web2/archive/what-is-web-20.html 
25. O’Reilly, T. We Are Moving Into the New World // [Online Resource]: Spiegel Online. Available at: http://www.spiegel.de/international/interview-with-web-guru-tim-o-reilly-we-removing-into-a-new-world-a-451152.html

26. Rakitov, A.I. Nash put' k informatsionnomu obshchestvu [Our Way to Information Society] / A.I. Rakitov // Teoriia i praktika obshchestvenno-nauchnoi informatsii [Theory and Practice of Social and Scientific Information] Moscow: INION, 1989.

27. Smolian, G.L., Tsygichko, V.N., Khan-Magomedov D.D. Internet v Rossii. Perspektivy razvitiia [Internet in Russia. Prospects of Development]. Moscow, 2004.

28. Stoliarov, Iu.N. Kritika termina "virtual'naia biblioteka" [Critics of the Term "Virtual Library"] [1997] // Bibliotekovedenie [Library Study]. Selected Works. 1960-2000. Moscow: Pashkov dom, 2001. P. 224.

29. Stoliarov, Iu.N. Biblioteka kak sistema [Library as a System] // Book. Research and Materials. Moscow: Kniga, 1984. Collection. 49. P. 59-79.

30. Sukiasian, E.R. Diskussionny klub "Termin" [Discussion Club "Term"] // Scientific and Technical Libraries. 2000. No. 6. P. 113-119.

31. Tikhomirov, V.P. Mir na puti $k$ smart education. Novye vozmozhnosti dlia razvitiia [The World on the Way to Smart Education. New opportunities for Development] // Otkytoe obrazovanie [Open Education]. 2011. No. 3. P. 22-28.

32. Tikhomirov, V.P. Mir na puti k smart-education. Novye vozmozhnosti dlia universitetov [The World to Smart Education. New Opportunities for Universities] // Innovatsionnoe razvitie ekonomiki Rossii: materialy III mezhdunarodnoi nauchno-prakticheskoi konferentsii [Innovative Development of Russian Economics: Proceedings of the III International Scientific and Practical Conference] Moscow: MESI Publishing House, 2010.

33. Vigurskiy, K.V. Elektronnye biblioteki: osnovnye poniatiia [Electronic Libraries: Main Terms] // Nauchnaiia kniga [Scientific Book] 2006. No.1. Pp. 116-119.

34. Vaneev, A.N. Metodicheskoe obespechenie bibliotechnoi deiatel'nosti [Methodical Provision of Library] // Metodicheskoe obespechenie bibliotechnoi deiatel'nosti [Methodical Provision of Library]. Saint-Petersburg: Professiia, 2004. P. 95-344.

35. Vigurskiy, K.V., Gorny E.A. Razvitie elektronnykh bibliotek: mirovoi i rossiiskiy opyt, problemy, perspektivy [Development of Electronic Libraries: International and Russian Experience, Problems and Prospects] // Internet i rossiiskoe obshchestvo [Internet and Russian Society] / edited by I. Semenova; Moscow Center of Carnegie. Moscow, 2002. P. 158-188. Available at: http://pubs. carnegie.ru/books/2002/08is/.

36. Voroiskiy, F.S. Osnovy proektirovaniia avtomatizirovannye bibliotechno-informatsionnykh system [Basics of Designing Automated Library and Information Systems]. Moscow: State Public Scientific and Technical Library of Russia, 2002. 389 p.

37. Zemskov, A.I., Shtainberg, Ia.L. Elektronnaya informatsiya i elektronnyye resursy: publikatsii $i$ dokumenty, fondy $i$ biblioteki [Electronic Information and Electronic Resources: publications and documents, funds and libraries]; edited by L.A. Kazachenkova. Moscow: FAIR Publishing House, 2007. 528 p. 


\title{
Электронная библиотека: генезис, тренды \\ от электронной библиотеки к смарт-библиотеке
}

\author{
Р.А. Барышев, О.И. Бабина, \\ П.А. Захаров, В.П. Казанцева, Н.О. Пиков \\ Сибирский федеральный университет \\ Россия, 660041, Красноярск, пр. Свободный 79
}

$\overline{\text { Статья предлагает к обсуждению основные тренды в развитии электронных библиотек и }}$ предпосылки к переходу на новый качественный уровень - ксмарт-библиотекам. Представлен исторический обзор формирования понятия «электронная библиотека» как в России, так и за рубежом. Отдельно выделяется многозначность термина «электронная библиотека» в России, в качестве синонима к которому выступает большинство терминов в нашей стране. При этом в рамках западного теоретизирования они часто укладываются в единое понимание иифровой библиотеки.

Обсуждается широкий спектр проблем электронных библиотек в разрезе многозадачности понимания роли библиотечного дела в публичной и вузовской среде. Отмечаются различия в подходах ввиду спеиифики вузовских задач.

В качестве решения авторы предлагают новый подход построения умной библиотеки на основе выявления и фиксации целей потребителя. Подход переворачивает парадигму библиотечного сознания, указывая, что главная роль в библиотеке отводится читателю, что идет в разрез со многими текущими размышлениями о том, что библиотека - это в первую очередь площади, фонды и персонал. В тексте раскрывается подход, когда, опираясь на современные технологии, можно существенно уменьшить значение последних и ввести в фокус исследователя потребности и роль читателя.

Ключевые слова: электронная библиотека, смарт-библиотека, библиотека, библиотечные услуги.

Научная специальность: 13.00.00 - педагогические науки, 08.00.00 - экономические науки. 